\title{
The Performance of by Turns Fermentation- Dryer for Vanilla (Vanilla Planifolia Andrews) Processing
}

\author{
Sitti Nur Faridah ${ }^{1}$, Abdul Waris ${ }^{1}$, and Haerani ${ }^{1}$
}

\begin{abstract}
The drying and fermentation are the processing steps which influence the quality of vanilla. Thus, an effort to produce instrument which can dry and ferment vanilla by turns automatically was done. Based on the test result on the instrument, it was known that the heater and heat-exchanger can function excellently. It can be seen from the increase of temperature after passing heater and heat-exchanger; and the decrease of air humidity in the drying chamber. The small differences of air flow speed between racks proved the uniformity of air flow speed in the drying chamber. The time and temperature control system showed temperature stability on drying process (i.e. $60^{\circ} \mathrm{C}$ ) and on fermentation process (i.e. $40^{\circ} \mathrm{C}$ ); moreover, temperature response reached $60^{\circ} \mathrm{C}$ and did not exceed the setting time (maximum 30 minutes). The water percentage depletion from $88 \%$ to $55 \%$ is relatively slow (in 5 days fermentation-drying process). The depletion is appropriate with the recommendation for fermentation-drying vanilla processing.
\end{abstract}

Keywords — drying, fermentation, temperature and vanilla

Abstrak-Proses pengolahan yang mempengaruhi mutu panili (Vanilla planifolia Andrews) adalah pengeringan dan fermentasi. Pada penelitian ini dirancang suatu perlatan yang berkerja secara otomatis untuk mode pengeringan dan fermentasi buah panili secara bergantian. Berdasarkan hasil pengujian sumber pemanas diketahui bahwa pemanas dan penukar panas dapat berfungsi dengan baik, hal ini dapat dilihat dari kenaikan suhu setelah melewati pemanas dan penukar panas serta kelembaban udara yang turun di dalam ruang pengering. Perbedaan kecepatan udara tiap rak yang relatif kecil membuktikan kecepatan udara seragam dalam ruang pengering. Sistem kendali waktu dan suhu menunjukan kestabilan suhu terjadi pada dua kondisi yaitu pengeringan $\left(60^{\circ} \mathrm{C}\right)$ dan fermentasi $\left(40{ }^{\circ} \mathrm{C}\right)$ dan respon suhu mencapai $60{ }^{\circ} \mathrm{C}$ tidak melewati setting time (maksimum 30 menit), dan penurunan kadar air dari $88 \%$ menjadi $55 \%$ relatif lambat (5 hari pengeringanfermentasi) sesuai yang direkomendasikan untuk pengeringan Panili.

Kata Kunci-pengeringan, fermentasi, suhu dan panili

\section{INTRODUCTION}

$\mathrm{G}$ enerally, vanilla (Vanilla fragans) is used as flavor enhanced and aroma strengthens in food and drinks [1]. In fact, in developing countries vanilla is also used as cosmetic ingredient. By this good potential and the high rate of vanilla price, some Indonesian farmers change their crop commodity into vanilla crop. However, farmer's knowledge regarding vanilla (especially the processing steps) is still low. The vanilla processing consists of four steps, i.e. wilted, fermentation, drying, and storage. From these four steps, drying and fermentation influence the quality of vanilla.

It is suggested that vanilla is dried for three hours, and then it is put on fermentation box until its water percentage is $50-55 \%$. In Indonesia, especially in South Sulawesi, these processing steps are not done, because these steps require more workers, especially if the quantity of vanilla to be processed is large. In fact, farmers just spread out the vanilla in the sun to dry for five hours, and then in the afternoon vanilla is covered using cloth or tarpaulin. Through this process, vanilla can become damage, moldy, and the drying process is not evenly distributed [2].

Sitti Nur Faridah, Abdul Waris, and Haerani are with Department of Agricultural Engineering, Fakultas Pertanian, Universitas Hasanuddin, Indonesia. E-mail: idajamal@yahoo.com.
To make the processing step easier, an instrument to dry and ferment vanilla by turn automatically is developed. Thus, the process no longer depends on weather and no longer requires many workers. Good performance of the instrument is required to achieve maximum result of the process. Therefore, an examination on instrument is done to find out its capabilities, so it can be used as reference for the user.

\section{METHOD}

\section{A. Fermentation-dryer Description}

The capacity of this fermentation - dryer is $20 \mathrm{~kg}$ by using parallel air flow type and electricity power. The instrument consists of (Figure 1): drying chamber in form of a box (the box wall is made from aluminum and stainless steel and the size is $\left.60 \times 65 \times 102 \mathrm{~cm}^{3}\right), 15$ pieces of drying rack in the size of $55 \times 37 \mathrm{~cm}^{2}$, heater as heat source, blower to flow air into the drying room, control box, discharge air channel, and intake air channel.

\section{B. Research Method}

Observation and measurement were done before and in the process of instrument operation. The measurement before operation involved the measurement of electricity power used in the dryer. On the other hand, the measurement in the process of fermentation-drying consists of: voltage measurement in the drying process to 
observe the voltage input in the dryer by using avometer; temperature measurement in five spots, i.e. $\mathrm{T}_{1}$ is temperature in the intake air channel, $\mathrm{T}_{2}$ is temperature in air channel which passes through heat-exchanger, $\mathrm{T}_{3}$ is temperature in thermo-controller, $\mathrm{T}_{4}$ is temperature in air channel after passes through heater, and $\mathrm{T}_{5}$ is temperature in air channel discharge; humidity measurement by using wet bulb thermometer and dry bulb thermometer (the measurements include outside air humidity and humidity after air passed heater, while relative air humidity can be known by using psychometric chart); air flow speed measurement in the drying chamber by using anemometer which was placed in front of air hole in the drying chamber (the measurements were in upper rack, middle rack, and lower rack); temperature stability observation to identify temperature transient response and temperature stability in the condition of instrument with load (it was done in three hours and 1 hour simulations for each drying process which is set in $60^{\circ} \mathrm{C}$, and fermentation process which is set in $40^{\circ} \mathrm{C}$ ); control precise observation by using timer in the control time movement from drying process to fermentation process; and weight reducing observation every three hours drying and 21 hours fermentation.

\section{Data Tabulation} [3]:

Evaporate water mass was calculated by using equation

$M_{o}=\frac{M_{1}-M_{2}}{100-M_{2}} x W_{b}$

where,

$\mathrm{M}_{0}$ : evaporate water mass $(\mathrm{kg})$

$\mathrm{M}_{1}$ : initial water percentage $(\%)$

$\mathrm{M}_{2}$ : last water percentage (\%) end

$\mathrm{W}_{\mathrm{b}}$ : material mass $(\mathrm{kg})$

Heat transfer rate on drying process can be calculated by using equation [3]:

$W=\frac{M_{0}}{t}$

where,

$\mathrm{W}$ : drying rate $(\mathrm{kg} / \mathrm{hour})$

$\mathrm{M}_{0}$ : water mass $(\mathrm{kg})$

$\mathrm{T}$ : drying time, on effective heater (hour)

Volumetric speed was calculated by using equation ${ }^{3}$ :

$V=A x v$

where,

A : longitudinal section width $\left(\mathrm{m}^{2} /\right.$ second $)$

$\mathrm{v}$ : dryer air speed ( $\mathrm{m} /$ second)

Dryer efficiency was calculated based on energy from drying air, fermentation air, and energy for evaporate material by using equation below.

Energy from drying air [3]:

$q_{t}=\rho V C p\left(T_{1}-T_{0}\right) T_{e f}$

where,

$\mathrm{q}_{\mathrm{t}}$ : energy from dryer air $(\mathrm{KJ})$

$\rho \quad:$ air density $\left(\mathrm{kg} / \mathrm{m}^{3}\right)$

$\mathrm{v}:$ volumetric speed $\left(\mathrm{m}^{3} /\right.$ detik)

$\mathrm{Cp}:$ heat capacity $\left(\mathrm{KJ} / \mathrm{kg}^{\circ} \mathrm{C}\right)$

$\mathrm{T}_{0}$ : environment temperature $\left({ }^{\circ} \mathrm{C}\right)$
$\mathrm{T}_{1}$ : inside instrument temperature $\left({ }^{\circ} \mathrm{C}\right)$

$\mathrm{T}_{\mathrm{ef}}$ : effective time for drying process (second)

Energy from fermentation air [3]:

$Q_{1}=\rho V C p\left(T_{1}-T_{0}\right) T_{e f}$

where,

$Q_{1}$ : energy from fermentation air $(\mathrm{KJ})$

$\rho:$ air density $\left(\mathrm{kg} / \mathrm{m}^{3}\right)$

$V$ : volumetric speed in fermentation chamber $\left(\mathrm{m}^{3} /\right.$ detik)

Cp : heat capacity $\left(\mathrm{KJ} / \mathrm{kg}^{\circ} \mathrm{C}\right)$

$\mathrm{T}_{0}$ : environment temperature $\left({ }^{\circ} \mathrm{C}\right)$

$\mathrm{T}_{1}$ : inside instrument temperature $\left({ }^{\circ} \mathrm{C}\right)$

$t_{\text {ef }}$ : effective time for fermentation process (second)

Energy for evaporate material [3]:

$Q_{b}=M w \times h f_{g}$

where,

$Q_{\mathrm{b}}$ : energy need to evaporate material $(\mathrm{KJ})$

$\mathrm{Mw}$ : water mass which is evaporated (water $\mathrm{kg}$ )

$\mathrm{hf}_{\mathrm{g}}$ : evaporation latent heat $(\mathrm{KJ} /$ water $\mathrm{kg})$

For drying efficiency was calculated by using Equation [3]:

$\eta p=\frac{Q b}{q} \times 100 \%$

where,

$\eta_{\mathrm{p}}:$ drying efficiency $(\%)$

$\mathrm{Q}_{\mathrm{b}}$ : energy need to evaporate material $(\mathrm{KJ})$

$\mathrm{Q}$ : energy from drying air $(\mathrm{KJ})$

Thermal efficiency was calculated as shown below. Energy total from heater [3]:

$E H=P x t$

where,

EH : energy from heater $(\mathrm{J})$

$\mathrm{P} \quad$ : heater power (watt) $=\frac{V^{2}}{R}$

$\mathrm{t}$ : fermentation and drying time/heater on effective (hours)

Thermal efficiency of fermentation-dryer ${ }^{3}$ :

$\eta t=\frac{\text { qtotal }}{E H} \times 100 \%$

where,

$\eta_{\mathrm{t}} \quad$ : instrument thermal efficiency (\%)

$\mathrm{q}_{\text {total }}$ : energy from drying and fermentation air : $\mathrm{q}_{1}+\mathrm{q}_{2}$ $(\mathrm{KJ})$

\section{RESULTS AND DISCUSSION}

\section{A. Heat Source}

The function of heat source is to heat intake air in the drying chamber. The heat source is heater and heatexchanger. The initial temperature of air intake in the dryer was $30^{\circ} \mathrm{C}$ (point 1 ); then after passing the heatexchanger (point 2), the temperature increased up to $44^{\circ} \mathrm{C}$; after that the air flowed to heater and came into drying chamber (point 3), at this point, the temperature reached $60^{\circ} \mathrm{C}$. Then air in the drying chamber passed heat-exchanger and the temperature decreased to $45^{\circ} \mathrm{C}$ (point 4 at Figure 2).

Based on this result, it is known that heat-exchanger can maintain air heat which passed heater. The result test 
proved that heater and heat-exchanger can function well due to the required temperature (i.e. $60^{\circ} \mathrm{C}$ ) could be reached and air heat from drying chamber could be used (as a result the amount of energy used is fewer).

It is shown from Figure 3, that external air humidity is constant (i.e. 75\%), whereas intake air humidity decreases to $16 \%$. Intake air to drying chamber after passed heat-exchanger and heater will increase so the humidity decreased. External air humidity decreases from $75 \%$ to $65 \%$ due to water vapor from material which flow outside the drying chamber. According to Sodha et.al. in the drying process, water vapor is released from material to the air [3].

Theoretically, the amount of power to dry $20 \mathrm{~kg}$ material from $85-80 \%$ of initial water percentage to 55$50 \%$ of water percentage in the temperature of $60^{\circ} \mathrm{C}$ was 552.9 watt. However, the amount of power to be supplied must be larger than theoretical power because energy lost which passed through wall, door gap, et cetera must be counted. As a result the amount of power to be supplied was 900 watt. The indicator of successful power supply can be seen from the amount of energy used to reach drying temperature $\left(60^{\circ} \mathrm{C}\right)$ with maximum setting time of 30 minutes (Figure 4).

The temperature increase is relatively rapid (i.e. from $28^{\circ} \mathrm{C}$ to $60^{\circ} \mathrm{C}$ in 21 minutes by using 900 watt power), thus the dryer has enough energy and its system can function well. According to Ogata, a good system is a system which its transient response showed lower rise time and over shoot [4].

\section{B. Blower Performance}

Blower is an instrument to drive air to heater, thus the air can be heated then flowed to the dryer. On the design of drying air need, $56.9 \mathrm{~kg} /$ hour or $0.0154 \mathrm{~m}^{3} / \mathrm{second}$ of blower rate of flow is prepared to dry $20 \mathrm{~kg}$ of material. The successful indicators on blower performance are first, the uniformity of air in each drying tray and second, electric current measurement must be the same with electricity current on name plate blower motor.

From Figure 5, it is shown that the higher the rack position, the bigger the air speed, with $0.02 \mathrm{~m} / \mathrm{second}$ difference between upper and middle racks and 0.03 $\mathrm{m} / \mathrm{second}$ difference between middle and lower racks. These differences due to the appearance of metal sheet joint between drying chamber floor and wall which impede air flow in the intake hole in the lower side. Electric current measurement in blower motor was 1.49 Ampere and the measurement in blower was 1.5 Ampere, therefore channel was wide enough and motor did not hold any load. The relatively lower differences of air speed in each tray mean blower can function excellent.

\section{Fermentation-dryer Control System}

\section{Timer system}

Successful indicators of timer system performance are first, air temperature can reach $60^{\circ} \mathrm{C}$ for \pm 0 minute and it can be steady for 3 hours, then decrease to fermentation temperature (i.e. $40^{\circ} \mathrm{C}$ ) and this steady for 21 hours; and second, the accurate shift time of drying process to fermentation process and then to drying process again and so on continuously and automatically until $55 \%$ water percentage is achieved.

In the test without material, the initial temperature was $28^{\circ} \mathrm{C}$ and the temperature increased to $60^{\circ} \mathrm{C}$ in 24 minutes. On the other hand, test with material showed average temperature in the drying chamber was $58^{\circ} \mathrm{C}$ and it was achieved after 24 minutes. The additional time needed to reach $60^{\circ} \mathrm{C}$ due to the transportation of water vapor from material and the optimal use of heat air in drying chamber. Hall mentioned that use of heat air in the drying chamber is more optimal with the presence of material to dry [5].

After 3 hours of drying process, the temperature decreased to $40^{\circ} \mathrm{C}$ and it was steady for 21 hours. This process continued until 55\% water percentage was achieved. This test result proved that fermentation-dryer can function very well, as the control system can set the time for the required temperature.

2. Temperature control system

Dryer temperature response is dyer capability to modify temperature in every set point change in thermocontroller. This capability relates to the available amount energy in dryer and physical condition of the dryer ${ }^{1}$.

Successful indicator in temperature control system was the setting time can be reached in a relatively short time (maximum 30 minutes) by using PID (Proportional, Integral, and Differential) auto-tuning for 900 watt and 1200 watt power.

It can be seen from Figure 6, that average initial temperature for each rack in the drying chamber with 900 watt power is $29^{\circ} \mathrm{C}$. After 15 minutes, the temperature increases to $58^{\circ} \mathrm{C}$, and then reaches $61^{\circ} \mathrm{C}$ in 21 minutes.

For 1200 watt power, average initial temperature was $28^{\circ} \mathrm{C}$ which increased to $61^{\circ} \mathrm{C}$ in 18 minutes (Figure 7). For 1200 watt power, the air temperature transient response was faster because the amount of power used was bigger, thus as a result the temperature increased faster. Ogata said that transient response measurement using PID tuning can work constant, so its sensitivity and response rate will become larger [4].

\section{Fermentation-dryer Unit}

Successful indicators for fermentation-dryer unit are first, vanilla water percentage decrease is relatively slow, and second, vanilla quality after fermentation-drying process

\section{Vanilla water percentage}

For 3 hours drying process, the initial water percentage (i.e. $87 \%$ wet base water percentage) would decrease to $82.68 \%$ in the upper rack, $82.40 \%$ in the middle rack, and $81.91 \%$ in the lower rack. After 3 hours drying process, the process would continue to fermentation process for 21 hours duration, and the water percentage decreased in average to $79.90 \%$ in the upper rack, $79.50 \%$ in the middle rack, and $77.82 \%$ in the lower rack.

The differences of water percentage decrease for each rack due to the highest temperature in the lower rack compared with middle and upper racks. The highest temperature in the lower rack was caused by the placement of heater or heater element in the lower part of 
the instrument. To reduce the highest temperature in the lower rack, an isolator (i.e. black paint plywood) was placed above the heater, thus water percentage decrease differences in each rack was relatively small.

It was needed 5 days to achieve targeted water percentage (i.e. 55\%). Based on this fact, the fermentation-dryer can function well because the water percentage decrease is relatively slow which is appropriate with recommended vanilla processing.

2. Vanilla quality

After fermentation-drying process of vanilla for 5 days and vanilla reached $55 \%$ of water percentage, it can be mentioned that the quality of vanilla is good. It is shown from vanilla pod which shown shiny dark brown color and had typically vanilla aroma. The vanilla quality after dried using dryer nearly similar to vanilla quality dried under sunrise, thus it is known that the fermentationdryer can function well.

\section{CONCLUSION}

Based on the increase of temperature from $30^{\circ} \mathrm{C}$ to $60^{\circ} \mathrm{C}$ after passed heater and heat-exchanger, and the decrease of air humidity in the drying chamber, it can be said that heater and heat-exchanger can function well. Air speed differences in each rack of dryer was relatively small, i.e. $0.025 \mathrm{~m} / \mathrm{second}$. Temperature stability presented on 2 conditions, i.e. on drying process $\left(60^{\circ} \mathrm{C}\right)$ and fermentation process $\left(40^{\circ} \mathrm{C}\right)$. Moreover, temperature response reached $60^{\circ} \mathrm{C}$ and did not pass the setting time, i.e. 30 minutes. Water percentage decrease from $88 \%$ to $55 \%$ was reached in 5 days fermentation-drying process. This is appropriate to recommended vanilla drying processing.

\section{REFERENCES}

[1] S. Setijahartini, "Pengeringan", Jurusan Teknologi Industri. Fatemeta, IPB, 1980

[2] A. Suwandi and S. Yuni, "Pengolahan dan pemasaran panili", Penebar Swadaya, Bogor, 2004.

[3] S.M. Sodha, K.N. Bansal, A. Kumar, K.P. Bansal, and M.A.S. Malik, "Solar crop drying", Boca Raton, Florida C R C Press Inc, 1987.

[4] K. Ogata, "Teknik kontrol automatik (sistem pengaturan)", Jakarta : Erlangga, 1997.

[5] C.W. Hall, "Drying farm corps", Michigan: Edward Brother Co, 1957.

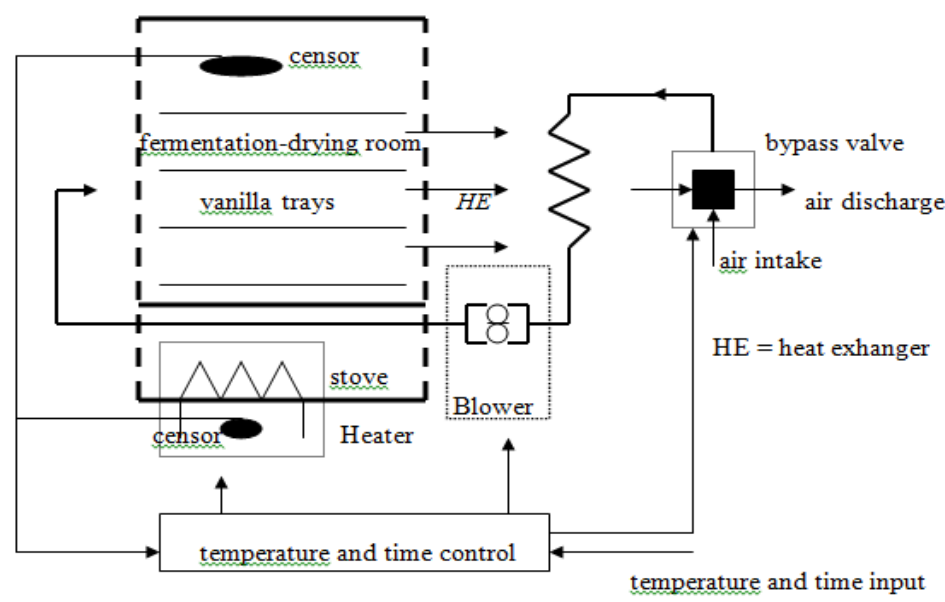

Figure 1. Fermentation-dryer scheme

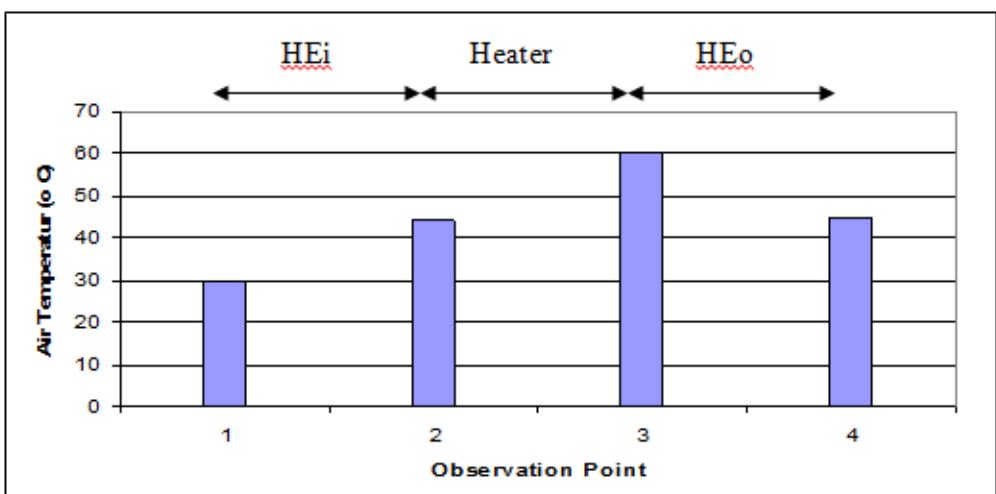

Note:

1. Intake air channel

2. Intake air channel which passed heat-exchanger (HEi)

3. Channel in drying chamber after passed heater (heater)

4. Channel drying chamber after passed heat-exchanger (HEo)

Figure 2. Air temperature profile in the dryer 


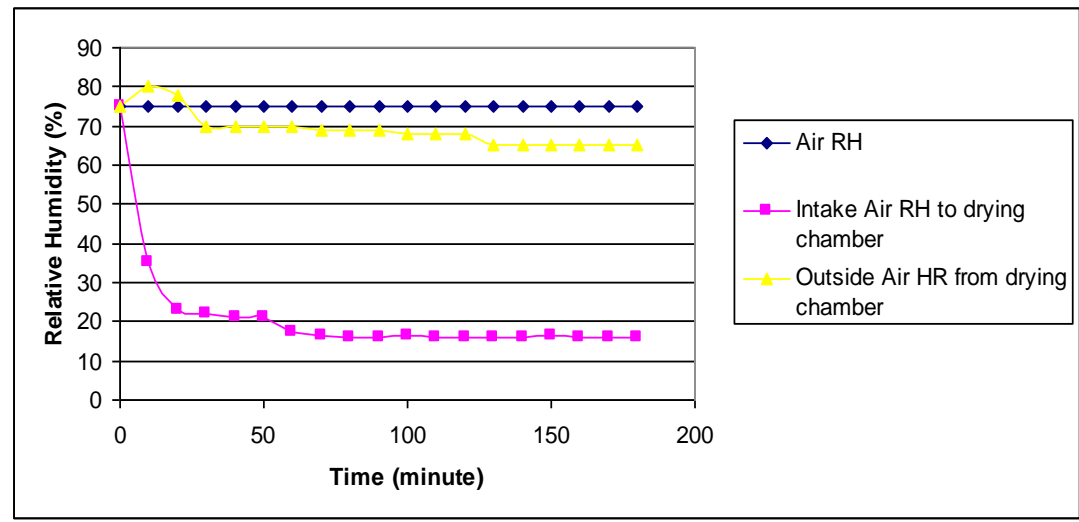

Figure 3. Air relative humidity on drying process

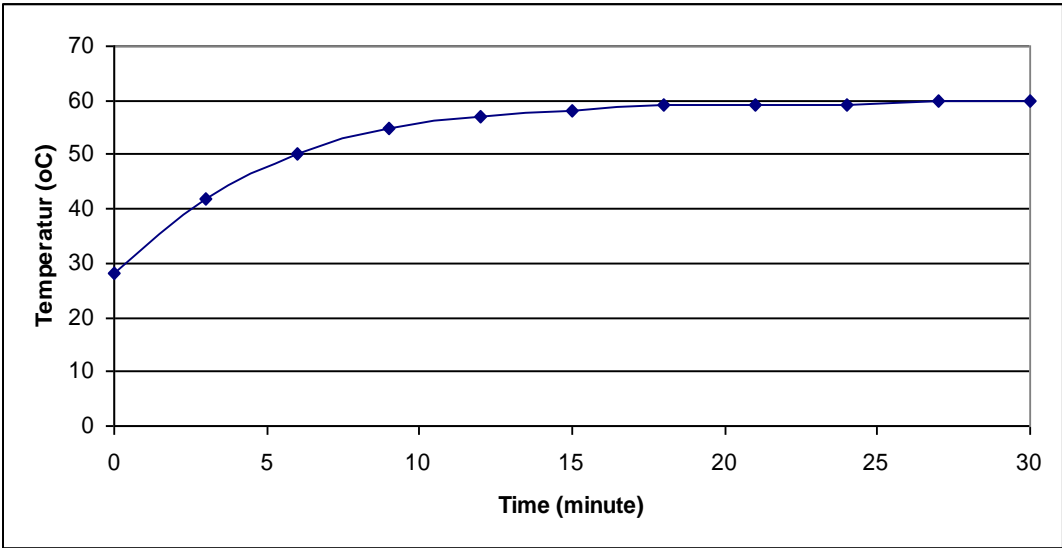

Figure 4. Transient response of average air temperature in the drying chamber

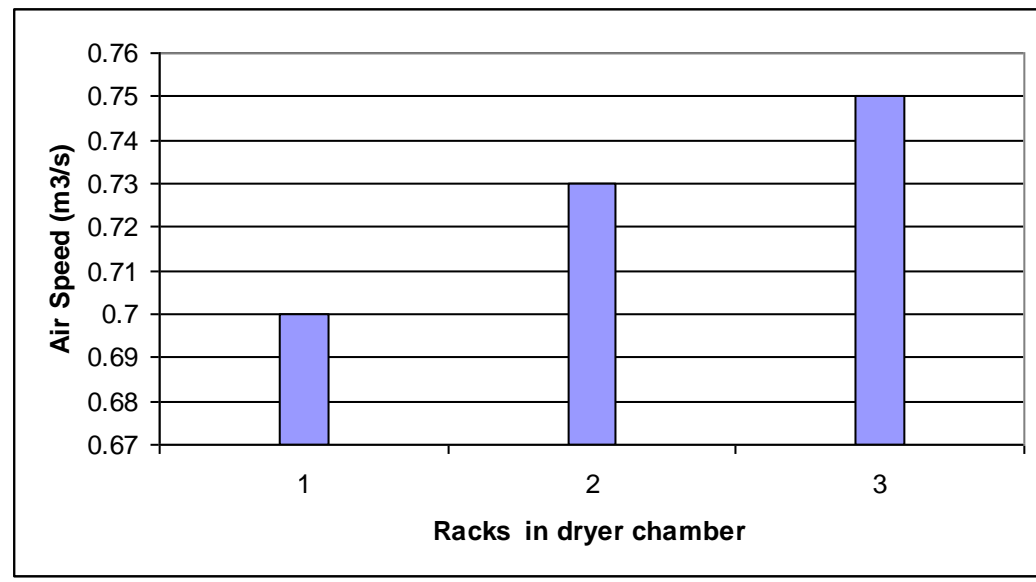

Note :

1. Lower racks in dryer chamber

2. Middle racks in dryer chamber

3. Upper racks in dryer chamber

Figure 5. Air speed in drying chamber 


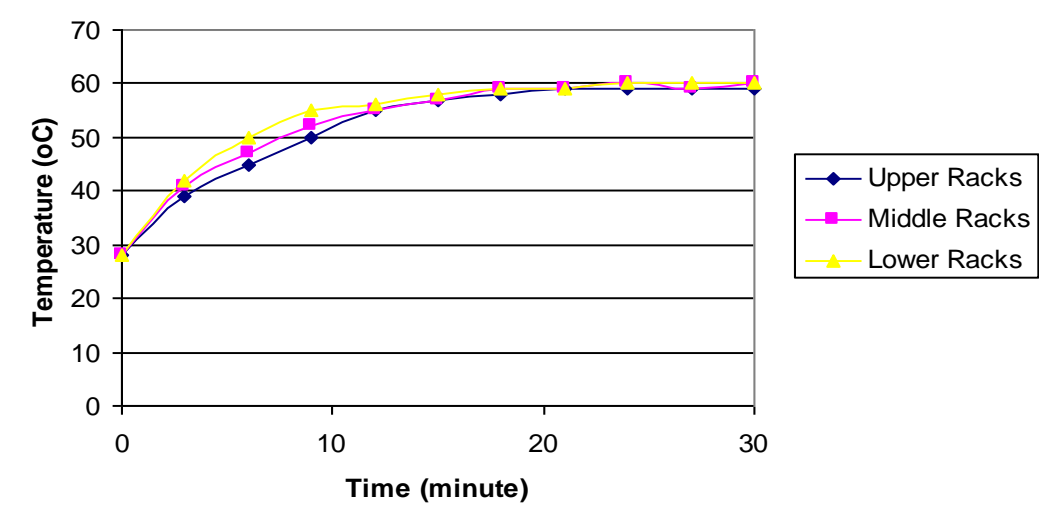

Figure 6. Air temperature transient response in 900 watt power

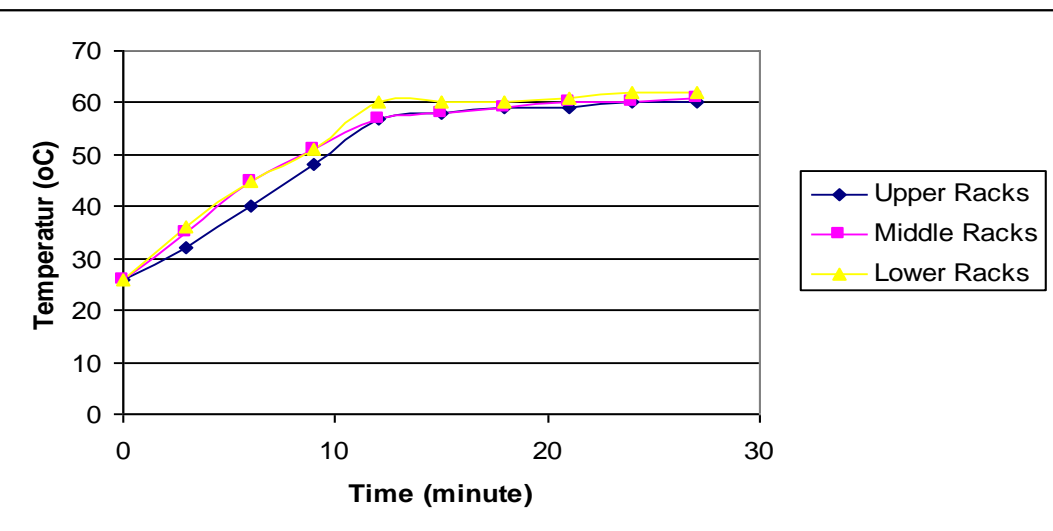

Figure 7. Air temperature transient response in 1200 watt power 